IZA DP No. 9672

Islamism and Gender Relations in the Muslim World as Reflected in Recent World Values Survey Data

Arno Tausch

Almas Heshmati

January 2016 


\title{
Islamism and Gender Relations in the Muslim World as Reflected in Recent World Values Survey Data
}

\author{
Arno Tausch \\ Innsbruck University \\ Almas Heshmati \\ Sogang University \\ and IZA
Discussion Paper No. 9672
January 2016 \\ IZA \\ P.O. Box 7240 \\ 53072 Bonn \\ Germany \\ Phone: +49-228-3894-0 \\ Fax: +49-228-3894-180 \\ E-mail: iza@iza.org
}

\begin{abstract}
Any opinions expressed here are those of the author(s) and not those of IZA. Research published in this series may include views on policy, but the institute itself takes no institutional policy positions. The IZA research network is committed to the IZA Guiding Principles of Research Integrity.

The Institute for the Study of Labor (IZA) in Bonn is a local and virtual international research center and a place of communication between science, politics and business. IZA is an independent nonprofit organization supported by Deutsche Post Foundation. The center is associated with the University of Bonn and offers a stimulating research environment through its international network, workshops and conferences, data service, project support, research visits and doctoral program. IZA engages in (i) original and internationally competitive research in all fields of labor economics, (ii) development of policy concepts, and (iii) dissemination of research results and concepts to the interested public.
\end{abstract}

IZA Discussion Papers often represent preliminary work and are circulated to encourage discussion. Citation of such a paper should account for its provisional character. A revised version may be available directly from the author. 


\section{ABSTRACT \\ Islamism and Gender Relations in the Muslim World as Reflected in Recent World Values Survey Data}

Ever since Goldin (1995) proposed the idea that there is a U-shaped female labor force participation rate function in economic development, empirical research is stunned by the question why the countries of the Middle East and North Africa (MENA) are characterized by such low rates of female labor force participation. This gap in labor economics research is all the more perplexing since gender equality, particularly in education and employment, significantly contributes to economic growth. The research strategy of the present paper is within a relatively new tradition in labor market research, initiated by the recent article by Besamusca, Tijdens, Keune and Steinmetz (2015), which does not exclude anymore the "religious factor" and what these authors call "gender ideology". Our analysis of the "gender ideology" of Islamism and gender values is based on an empirical analysis of World Values Survey data. In recent economic theory, Carvalho (2013) maintained that Muslim veiling is a strategy for integration, enabling women to take up outside economic opportunities while preserving their reputation within the community. The empirical data clearly support a pessimistic view. We show that Muslim Feminism, which implies according to our data analysis the rejection of the twin brothers - Islamism and the veil - and the democracy movement in the Muslim world are closely interrelated. Thus, it is imperative that Western Feminism develops solidarity with Muslim Feminism, and that labor economics does not exclude anymore "the religious factor" from the analytical frameworks explaining low female labor force participation rates.

JEL Classification: $\quad$ A13, C43, F66, J15, J16, J21, J42, N30, Z12

Keywords: social values, religion, female labor participation, political economy, comparative study, sociology of economics, economics of gender, index numbers, factor analysis, World Values Survey

Corresponding author:

Almas Heshmati

Department of Economics

Sogang University

Baekbeom-ro (Sinsu-dong \#1), Mapo-gu

Seoul 121-742

Republic of Korea

E-mail: heshmati@sogang.ac.kr 


\section{Background}

Ever since Goldin (1995) proposed the idea that there is a U-shaped female labor force participation rate function in economic development, empirical research is stunned by the question why the countries of the Middle East and North Africa (MENA) are characterized by such low international rates of female labor force participation (Gaddis and Klasen, 2014; Ganguli, Hausmann and Viarengo, 2014; Lechman and Kaur, 2015; Tsani, Paroussos, Fragiadakis, Charalambidis and Capros, 2015; Verme, 2015; Verme, Barry and Guennouni, 2014). The typical verdict of one of these recent empirical studies on the low female labor force participation rate in the MENA region was that the U-shape hypothesis per se does not provide clear leads on why female labor force participation rates in the MENA region are so low (Verme, Barry and Guennouni, 2014). This gap in labor economics research about a vital tendency in the economic development in one of Europe's most important neighboring regions is all the more perplexing since there seems to be a growing agreement in recent literature (de Haan, 2015; Kabeer, 2012; Kabeer and Natali, 2013) that per se gender equality, particularly in education and employment, significantly contributes to economic growth (Gaddis and Klasen, 2014). The educational deficiencies in the region, plausibly leading to so low female participation rates in labor markets in addition are well-known in international labor economics and have been highlighted once more in a recent study by the Brookings Institution (Steer, Ghanem and Jalbout, 2014). And, what's more, the MENA region is not only important for geographically adjacent Europe because the region is becoming such an important trading partner and location of production, but also in geo-strategical and also sheer demographic terms, highlighted by the recent "European refugee crisis". Recent research in labor economics thus already highlighted the importance of differential labor force participation rates of different cohorts of migrants in the leading countries of global inwards immigration over recent years (Donato, Piya and Jacobs, 2014).

The research strategy of the present paper is within the new tradition in labor market research, initiated by the recent article by Besamusca, Tijdens, Keune and Steinmetz (2015), which does not exclude anymore the "religious factor" and what these authors call "gender ideology".

Without question, international social science contributions published on the European "refugee crisis" of summer 2015 and beyond hitherto did not yet focus on the labor market and gender policy implications of what it will mean for Europe to integrate hundreds of thousands of young men from a mostly traditional environment in such countries as rural Syria, Iraq, Pakistan or Afghanistan. The already published literature (Baldacchino and Sammut, 2015; Carpenter, 2015; Carrera and Lannoo, 2015; Cooper, 2015; Hann, 2015; Hildebrandt, 2015; Martin, 2016; Mertes, 2015; Peters and Besley, 2015; Stewart, 2015) could not foresee that just as the Calendar Year 2016 began, international publics could read in the global media ${ }^{1}$ that hundreds of women celebrating New Year's Eve in one of the major cities of Germany, Cologne, became victims of mass sexual assault by "men with North African and Middle Eastern appearances", as the German newsmagazine "Der Spiegel" put it."

Most German politicians have been careful in their initial responses to the Cologne events so as to avoid playing into the hands of what is most often being called in Europe nowadays "right-wing Islamophobias". For days, German media were silent on the Cologne events and did not even report them at all, perhaps thinking that media can adapt to the behavior of the

\footnotetext{
${ }^{1} \mathrm{http} / /$ www.spiegel.de/international/germany/cologne-shocked-by-sexual-assaults-on-new-years-eve-a1070583.html\#spLeserKommentare. All downloads of this article: January 7, 2016.

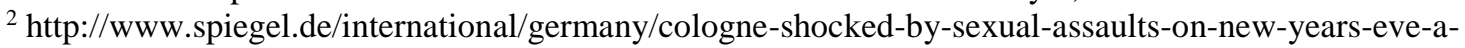
1070583.html\#spLeserKommentare
} 
ostrich in moments of tension and conflict. ${ }^{3}$ Already in October 2015, 54\% of Germans were preoccupied or very preoccupied with the unabated influx of refugees. ${ }^{4}$ It is noteworthy to reflect a moment on the national origins of these refugees in order to highlight that a sizeable proportion of them does not even come from zones of war and conflict: only a minority was from Syria (33.8\%), Afghanistan (6.7\%), and Iraq (6.3\%), while such countries as Albania (13.3\%), and Kosovo (8.4\%) were ranked second and third, with sizable contingents also coming from Serbia (4.2\%), Eritrea (2.6\%), Macedonia (2.2\%), and Pakistan (1.9\%). ${ }^{5}$ Now, a simple glance at these statistics will convince anyone that Albania, Kosovo, Serbia and Macedonia are already full candidates or official "potential candidates" (EU-newspeak) for EU-membership, ${ }^{6}$ implying that they are well on their way to fulfill the so-called Copenhagen criteria of EU-membership, i.e.:

- The stability of institutions guaranteeing democracy, the rule of law, human rights and respect for and protection of minorities;

- A functioning market economy and the capacity to cope with competition and market forces; and

- The administrative and institutional capacity to effectively implement European Union law and the ability to take on the obligations of membership. ${ }^{7}$

The Mayor of the City of Cologne, Henriette Reker, meanwhile excelled all other German political leaders by even adding that women themselves should be careful to avoid such attacks as the ones in Cologne in future. ${ }^{8}$ Reker stated that women would be just advised to keep a certain distance of more than an arm's length to people who are not known so they can avoid such attacks in future, and that's it, that's the solution. ${ }^{9}$

Whatever happened in Cologne, migration and gender will surely become THE issue in the coming months and years in Western countries. Most Western scientific publics identifying with the goals of an "Open Society" (Popper, 2012) still would reject the notion of cultural differences on gender issues between the Muslim world and the West (Moghadam, 2002). But Feminists from the Muslim world themselves increasingly criticize Western Feminism for overlooking "oppressive gender relations" in the non-Western world, and there seems to be some consensus in this literature (Mojab, 2001; Mir-Hosseini, 2011) that the Islamist rallying cry of 'Return to Shari' a' led to regressive gender policies, with devastating consequences for women: compulsory dress codes, gender segregation, and the revival of cruel punishments and outdated patriarchal and tribal models of social relations (Mir-Hosseini, 2011).

This is the central and inescapable topic of this article. This gender policy clash of civilizations now looms ahead all over Europe, and is all the greater because, without question, gender equality policies are nowadays very high on the agenda of Western democracies. The very same European governments, welcoming hundreds of thousands of migrants from the countries so aptly characterized by Mir-Hosseini, 2011 are untiringly promoting "gender

\footnotetext{
${ }^{3}$ http://www.faz.net/aktuell/feuilleton/medien/fuer-ard-und-zdf-ist-silvester-in-koeln-weit-weg-14000633.html and http://de.statista.com/statistik/daten/studie/76095/umfrage/asylantraege-insgesamt-in-deutschland-seit-1995/ Germany registered over 200.000 asylum applications in 2014 and over 400.000 asylum applications in 2015. ${ }^{4} \mathrm{http}$ //www.faz.net/aktuell/politik/fluechtlingskrise/allensbach-umfrage-mehrheit-besorgt-ueber-folgen-derfluechtlingskrise-13866950.html

${ }^{5}$ https://www.bamf.de/SharedDocs/Anlagen/DE/Downloads/Infothek/Statistik/Asyl/statistik-anlage-teil-4aktuelle-zahlen-zuasyl.pdf;jsessionid=FAABBCD54FDD55F9F41E82052DD6D436.1_cid359?_blob=publicationFile

${ }^{6} \mathrm{http}: / /$ ec.europa.eu/enlargement/countries/package/index_en.htm

${ }^{7} \mathrm{http}: / /$ ec.europa.eu/enlargement/countries/package/index_en.htm and http://ec.europa.eu/enlargement/policy/glossary/terms/accession-criteria_en.htm

${ }^{8} \mathrm{http}: / / \mathrm{www}$.theatlantic.com/international/archive/2016/01/cologne-attacks/422844/

${ }^{9} \mathrm{http}: / /$ www.theguardian.com/world/2016/jan/06/cologne-attacks-mayor-women-keep-men-arms-lengthgermany
} 
mainstreaming", which is now on top of any priority list of European Union policy makers, in temporal correlation with financial austerity. ${ }^{10}$

A recent leading empirical study on these issues led two researchers who employed sophisticated statistical models and large-scale opinion surveys to the conclusion that Muslim support for patriarchal values is robust against various controls; and rising levels of education, labor market participation, and an emancipative trend diminish Muslim support for patriarchy, especially among women (Alexander and Welzel, 2011).

So, what connections - if any - exist between traditional gender roles in the Muslim world and the Islamist challenge? Is the Muslim veil an innocent symbol of religious devoutness, as most literature on the subject nowadays still suggests, or is it part of a larger anti-Western syndrome, and can it be contributing to an anti-Western cultural identity that under certain circumstances even can lead to more and more Islamism?

While most media and mainstream political forces in such Western countries as the U.K. or Germany still rather tend to view the "veil" simply as a "protective shield", 11 allowing Muslim women their emancipation in their respective cultures, the cases of Ait Boulahcen, the Paris terrorist, who started wearing the niqab in parallel with her overall transformation from a "party girl" into a terrorist in the time span of six months before the attacks, ${ }^{12}$ and of Tashfeen Malik, the niqab wearing mass killer in San Bernardino, have caught the imagination of global political commentators, integrations experts and analysts ever since.

There are now foreseeable heated debates everywhere on "banning the burka" (as the niqab is often incorrectly being called) in many Western countries, including in the Lombardia region of Italy and in Germany. While from the 1920s to 2008 such a headscarf ban indeed was in force in Kemalist Turkey, actually there are such bans in force in France and in Belgium, and also in the majority Muslim countries Albania and the Kosovo. ${ }^{13}$

In purely legal terms, such a ban even could well correspond to international and European law, since the European Court of Human Rights ${ }^{14}$ recently held by a majority that there had been no violation by the French ban on the headscarf from public life of Article 8 (right to respect for private and family life) of the European Convention on Human Rights, and no violation of Article 9 (right to respect for freedom of thought, conscience and religion); and also there had been no violation of Article 14 (prohibition of discrimination) of the European Convention. ${ }^{15}$

Prominent social scientific studies on the subject are divided in their opinion. A leading feminist study published in 2012 (Mahmood, 2012) pleaded in defense of the veil and said that more attention should be given to Islamic virtues of female modesty or piety, especially given that many of the women who have taken up the veil frame their decision precisely in these terms.

A large amount of well-received social science literature debated the issues from the viewpoints of feminist traditions and Muslim traditions and rather asked whether there is a general compatibility or incompatibility of these two and whether or not they might converge (Ahmed, 1992; Moghissi, 2005; Moghadam, 1994; Bouachrine, 2014). Valuable as insights from those studies may be, essentialistic arguments, based on philosophical or sociological "theory" - one way or the other - often overlook the facts of social mass realities and the who's,

\footnotetext{
${ }^{10} \mathrm{http}$ //eige.europa.eu/gender-mainstreaming.

${ }^{11} \mathrm{http}: / /$ en.qantara.de/content/muslim-women-on-the-niqab-the-veil-as-a-protective-shield

${ }^{12} \mathrm{http}$ ://www.theguardian.com/world/2015/nov/20/hasna-ait-boulahcen-party-girl-who-became-paris-suicidebomber

${ }^{13}$ Wading through the many regulations and debates, the Huffington Post's collection of articles is very helpful: http://www.huffingtonpost.com/news/burqa-ban/

14 This institution belongs to the architecture of the Council of Europe, and not the European Union

${ }^{15}$ http://www.huffingtonpost.com/raza-habib-raja/burqah-ban-multiculturali_b_5551825.html
} 
what's, to whom's, with what effects, when's and why's of the social processes in Muslim societies, which are now beginning to be studied with the help of large scale representative surveys in the framework of the "World Values Survey".

A data oriented study, what accepting "wearing the veil" implies and what it does not, is all the more necessary, since many earlier studies on the subject (Carol and Koopmans, 2013; Ghumman and Ryan, 2013; Göle, 2014; Helbling, 2014) by and large eluded the question on what actually proponents and opponents of the veil among Muslim publics actually think on the subject themselves, and how these opinions correlate with other attitudes, from democracy to trust in central state security institutions, the separation of religion and state, the overall advancement of women in society and central personal values, manifesting themselves in the opinions on whether children should be educated to be tolerant or obedient.

Leading studies in this field are now beginning to be received in the larger literature on Muslim societies, and it is worthwhile to evaluate and develop this research tradition in the present essay (Adamczyk, 2013; Alemán and Woods, 2015; Blaydes and Linzer, 2012).

Blaydes and Linzer, in their path breaking study, 2012, contended for example that the issues under scrutiny here have a strategic implication for the national security of the West, because forms of piety and religiosity can become part and parcel of the syndrome of AntiWesternism.

Norris and Inglehart, in their well-known 2012 study, already and even prophetically foresaw the necessity of such empirical studies on gender and Muslim societies by saying that they expect to find strong contrasts between Muslim migrants and the increasingly secular Western publics (Norris and Inglehart, 2012).

Among the vast empirical literature on the subject, Lussier and Fish, 2012, found out that in the global sample, Muslims express more traditional views toward sex-based inequality than non-Muslims do. The percentage of Muslims who agree or strongly agree that a university education is more important for a boy than a girl and the percentage of Muslims who agree that when jobs are scarce men should have more right to a job than women are more than double the percentage of non-Muslims who agree with these statements (Lussier and Fish, 2012).

Norris and Inglehart, 2012 could show that orientations that are established in one's primary socialization, relatively early in life, such as gender roles, ethnic identities, and religious values, are likely to become part of one's core identity, which is relatively resistant to change. Conversely, the formative period for political and economic values seems to occur later in life; such orientations, instilled in one's secondary socialization, are more open to change. Consequently, Norris and Inglehart expect that migrants would be more likely to change their values concerning politics than those concerning religion and gender roles. Though Muslim publics clearly support the goal of democracy, a substantial cultural gap exists between Islamic and Western societies concerning gender equality and sexual liberalization. Moreover, this gap seems to have widened in recent years because, while advanced industrial societies in North America, Western Europe, Japan and Australia have experienced rapid cultural change on issues such as tolerance of homosexuality, divorce and gender equality, the values of preindustrial societies have been changing relatively slowly.

\section{Methods and data}

This essay is a continuation of earlier studies on the subject (Tausch, Heshmati and Karoui, 2015), and again draws on the data from the "World Values Survey", the world's largest 
collection of representative opinion surveys, covering some $90 \%$ of the global population. ${ }^{16}$ The chosen SPSS data-files from the WVS data base is "WVS_Longitudinal_1981_2014".

The global Muslim sample (71,773 representative Muslims) was drawn from this WVS file by selecting persons with the denominations given as "Druse" (18), "Muslim" $(62,115)$, "Shia" $(4,058)$, and "Sunni" $(5,583)$ from a large number of countries. ${ }^{17}$ Our analysis is thus based on one of the largest surveys of global Muslim opinion ever undertaken, and covers a large portion of the global population.

The WVS data are freely available to any person across the globe. In order not to overburden our essay with tables and statistical data, we have made our results available for the specialists, interested in following up more closely our research results in the Appendix to this essay (Appendix Table 1-11). Any researcher around the globe with a proper access to the SPSS XXII statistical program and the WVS freely available data should be able to reproduce our findings on a 1:1 basis. For this reason, our presentation of the results will be rather brief.

In our empirical work, we took great care to properly take into account the fact that often in the World Values Survey project, the highest numerical values of a variable express something else than the original WVS variable labels. Our appendix tables take all these points into proper consideration and guide the interested readers on what true variable labels the highest numerical values of the World Values Survey data actually express in our multivariate analysis.

Our multivariate analysis uses the SPSS XXII standard statistical package for the social sciences, and we use ordinary cross tables, partial correlations and the promax factor analysis procedures as the chosen statistical methods presented at length in a recent work (Tausch, Heshmati and Karoui, 2015). Occasionally, our World Values Survey data were augmented by country-level results from the PEW Research Institute in Washington DC. ${ }^{18}$

\section{Mass support for traditional gender roles in the Muslim world}

Focusing on compulsory dress codes, gender segregation, and the revival of cruel punishments and outdated patriarchal and tribal models of social relations (Mir-Hosseini) or on forced marriages, polygamy, domestic violence, and honor killings, as well as patriarchal beliefs about the traditional roles of women in the family, and the symbolic wearing of the hijab, niqab and burqa (Norris and Inglehart, 2012) amounts to willing to grasp the nettle and touching a sore spot in the entire debate about migration, integration, and asylum.

By and large, the data from the present work confirm the skepticism inherent in the works of Mir-Hosseini and Norris and Inglehart, referred to above, about a real clash of civilizations regarding gender issues between the West and the Muslim world.

To begin our short and also shocking survey of the existing data and their respective country level values, we looked at a PEW data series on how people in Muslim countries prefer

\footnotetext{
${ }^{16} \mathrm{http}: / / w w w . w o r l d v a l u e s s u r v e y . o r g / w v s . j s p$

${ }^{17}$ The sample include countries and territories: Albania, Algeria, Andorra, Argentina, Armenia, Australia, Azerbaijan, Bangladesh, Belarus, Bosnia, Bosnia, Brazil, Bulgaria, Burkina Faso, Canada, China, Colombia, Croatia, Cyprus, Egypt, Estonia, Ethiopia, Finland, France, Georgia, Germany, Ghana, Great Britain, Guatemala, Hong Kong, Hungary, India, Indonesia, Iran, Iraq, Israel, Jordan, Kazakhstan, Kyrgyzstan, Latvia, Lebanon, Libya, Lithuania, Macedonia, Malaysia, Mali, Mexico, Moldova, Montenegro, Morocco, Netherlands, New Zealand, Nigeria, Norway, Pakistan, Palestinian Occupied Territories, Peru, Philippines, Romania, Russia, Rwanda, Saudi Arabia, Serbia, Serbia and Montenegro, Singapore, Slovenia, South Africa, South Korea, Spain, Sweden, Switzerland, Taiwan, Tanzania, Thailand, Trinidad and Tobago, Tunisia, Turkey, Uganda, Ukraine, United States, Uzbekistan, Viet Nam, Yemen, Zambia, Zimbabwe.

${ }^{18} \mathrm{http}: / /$ www.pewglobal.org/
} 
women to dress in public. ${ }^{19}$ Respondents in the survey were shown images of women, ranging from a Lady with no hair cover to the full scale "Afghan" type of "Burka". Except for the Lebanon with its large Christian minority population, acceptance of a Western dress style by Muslim publics has now become a minority affair, even in the once staunchly secularist and head-scarf-free Kemalist Turkey. In Lebanon, the percentage accepting a Western female hairstyle is $49 \%$, in Turkey it is $32 \%$, and in Tunisia it is $15 \%$, while it is below 5\% in Egypt, Iraq, Saudi Arabia, and Pakistan.

The PEW data also reveal the astonishing rate of Muslim acceptance of the opinion that a wife should always obey her husband. In 20 of the 23 countries where the question was asked, at least half of Muslims believe a wife must always obey her spouse. ${ }^{20}$ By contrast, the nowadays seemingly helpless consolidated legislation of the European Union contains 52 text pieces which mention the term "gender mainstreaming" and 117 text pieces which mention the term "gender discrimination". ${ }^{21}$ Did any of the politicians in Europe, talking about the "culture of welcoming refugees" ever reflect on what mass migration from predominantly Muslim countries will mean for the future of gender equality in Europe for the coming generations?

In Malaysia, Afghanistan, Indonesia, Tunisia, Morocco, Tajikistan, Thailand, Pakistan, Bangladesh, Palestinian Territories, Egypt, Uzbekistan, Jordan, Kyrgyzstan, female obedience in marriage is supported $3 / 4$ or more of the total Muslim population, and in Lebanon, Russia, Turkey, Azerbaijan and Kazakhstan, it is supported by more than half of the total Muslim population. Only in the former Communist Balkan countries of Kosovo, Albania and Bosnia, these percentages are below $50 \%$.

A quick glance at the new World Values Survey data re-iterates the PEW findings. In our statistical Tables we show the aggregate country values of religiously supported traditionalism in the region, measured by support for the veil and also the support for polygamy.

More than $70 \%$ of Muslim publics think that the veil is important or very important, such as in Algeria, Bangladesh, Egypt, Indonesia, Iran, Iraq, Jordan, Nigeria, Pakistan, and Saudi Arabia. Only Turkey with its tradition of Kemalism still stands out as a statistical outlier and a veil support rate of only $14 \% .{ }^{22}$ However, in recent years there are tendencies for Islamists comeback to weaken the secular policies of Turkey.

Sizeable proportions of global Muslim publics not only support the veil, but also another concept, completely incompatible with civil law in the West - the idea of institutionalized polygamy. In Nigeria, a sizeable majority of almost $3 / 4$ of the entire Nigerian Muslim population supports it, and in Algeria, Iraq and Saudi Arabia, this support rate is 2/5; while in other mainly Muslim countries, the support rates are less but still a considerable minority. It also has to be observed that also a sizeable minority of Turkish Muslims - 1/6 - in fact support polygamy, and Turkey, according to the combined wisdom of the European political elites, is an official EU member candidate country since the European Council meeting in Helsinki in 1999! That is to say, the combined interaction of the elites in Brussels and Ankara took 17 years to prepare the country for implementing European Union law, of which gender policy is an integral part,

\footnotetext{
${ }^{19} \mathrm{http}: / /$ www.pewresearch.org/fact-tank/2014/01/08/what-is-appropriate-attire-for-women-in-muslim-countries/

${ }^{20} \mathrm{http}$ ://www.pewforum.org/2013/04/30/the-worlds-muslims-religion-politics-society-women-in-society/

${ }^{21} \mathrm{http}: / /$ eur-

lex.europa.eu/search.html?textScope0=te\&qid=1452181322988\&DTS_DOM=EU_LAW\&type=advanced\&lang $=$ en $\&$ andText $0=$ gender\%20mainstreaming \&SUBDOM_INIT=CONSLEG\&DTS_SUBDOM=CONSLEG

${ }^{22}$ The data from the PEW on the proper way to cover/not to cover the hair and from the World Values Survey on the importance of women wearing the veil seem to suggest divergent percentages for the case of Turkey. But looking at the wording of the questions the differences are explained: while more than 2/3 of Turkish Muslims think that it is proper for a woman to cover her head, only $1 / 6$ think it is important.
} 
with the hallmark of a still existing support rate for polygamy among the Turkish population to the tune of $1 / 6$ !

And although some praiseworthy Muslim publics in some countries around the globe are less inclined than their non-Muslim counterparts to accept male domestic violence against women, our evaluation of the "World Values Survey" data shows that more than a third and, in some countries, more than half of the entire Muslim population accepts male domestic violence against women (India; Thailand; Iraq; Rwanda; Mali; Egypt; Bahrain; Algeria; Lebanon; Ghana; Burkina Faso; Philippines; Malaysia; Nigeria; Russia; Singapore; Uzbekistan; Kuwait; Palestinian Territories; Germany; Yemen; Kazakhstan; Kyrgyzstan; Morocco; and China). ${ }^{23}$

\section{The case for a Muslim feminist perspective, critical of the veil}

\section{A. correlations of opinions on the Western dress code, the veil and polygamy}

In view of these tendencies, a case could be made for a kind of neo-Kemalism in the West and also in those Muslim countries which strive for Western political orientations and reforms (Coşar and Yeğenoğlu, 2011; Ozcetin, 2013; Dedeoglu, 2013; Kandiyoti, 2012; Arik, 2015; Cronin, 2014). For the empirical social scientist, it is clear at least that the acceptance of the veil and of polygamy cannot be separated from attitudes which largely must be deemed as incompatible with an overall functioning "Open Society".

The following indicators of Islamism significantly correlate with the acceptance of the veil (variables mentioned in descending order of their significant positive correlations):

- Politicians who don't believe in God are unfit for public office,

- Violation of Islam for male and female university students to attend classes together,

- Only laws of the Shari'a can be accepted,

- Men make better political leaders than women do,

- A truly Islamic country should not have a parliament with the right to pass laws,

- University is more important for a boy than for a girl,

- Reject neighbors: Jews,

- Religious leaders should influence how people vote,

- Exposure to the culture of the US and other Western countries harmful effect on our country,

- Islam requires country with majority of Muslims be governed by men of Islamic learning,

- Wife must obey,

- Important child qualities: obedience,

- Islam requires that political rights of non-Muslims should be inferior to those of Muslims,

- No confidence: The European Union, and

- No confidence: The United Nations.

Also, the significant partial correlations of accepting polygamy (again mentioned in descending order of the size of the correlation coefficient) show that an open, corruption and prejudice free, gender-justice oriented and pro-Western society is not supported at all by support for polygamy:

\footnotetext{
${ }^{23}$ A very practical introduction to the logic of error margins in sample-based survey results is to be found in http://ec.europa.eu/public_opinion/archives/eb/eb83/eb83_first_en.pdf. Clauß and Ebner, 1970, and a host of other literature recommend discarding survey results from samples which are smaller than 30 .
} 
- No confidence: NATO,

- Reject neighbors: Homosexuals,

- Reject neighbors: Jews,

- University is more important for a boy than for a girl,

- Men make better political leaders than women do,

- Democracies are indecisive and have too much squabbling,

- Justifiable: avoiding a fare on public transport,

- Islam requires country with majority of Muslims be governed by men of Islamic learning,

- No confidence: Parliament,

- Important child qualities: obedience,

- A truly Islamic country should not have a parliament with the right to pass laws,

- Competition harmful, and

- Justifiable: cheating on taxes.

\section{B. Evidence from the multivariate analysis}

A neo-liberal economist, on the basis of a mathematical model and a data analysis, based on global survey results, recently stated in one of the leading journals of economic science that:

"Veiling is a strategy for integration, enabling women to take up outside economic opportunities while preserving their reputation within the community. This accounts for puzzling features of the new veiling movement since the 1970s. Veiling also has surprising effects on the intergenerational transmission of values. Compulsory veiling laws can lead to a decline in religiosity. Bans on veiling can inhibit social integration and increase religiosity." (Carvalho, 2013)

But our multivariate analysis suggests a totally different perspective. Our analysis uses the World Values Survey data on what Muslim publics actually think on the veil, on polygamy and on female obedience themselves, and how these opinions correlate with other attitudes, from democracy to trust in central state security institutions such as the Armed Forces, the separation of religion and state, the overall advancement of women in society and central personal values, manifesting themselves in the opinions on whether children should be educated to be tolerant or obedient. The variables chosen to measure these concepts were:

- Important child qualities: tolerance and respect for other people,

- Important child qualities: religious faith,

- Important child qualities: obedience,

- University is equally important for a boy and for a girl,

- Not important: Woman wearing the veil,

- Reject: more than one wife,

- Reject: wife must obey,

- No confidence: Armed Forces,

- Bad having a democratic political system,

- Never attend religious services,

- Reject: politicians who don't believe in God are unfit for public office,

- Gender (female), and

- Highest educational level attained.

After analyzing their correlation matrix, the SPSS XXII program extracted five factors, whose Eigenvalues corresponded to the standard criterion of being greater than 1.0. Applying 
the promax factor rotation routine, the five factors, described in detail in our Appendix Table 10 can be interpreted as:

- Rejecting Islamism and the veil,

- Feminism,

- Upper strata distanced from the Army,

- Pro-democracy movement, and

- Authoritarian personality.

The factor "rejecting Islamism and the veil" is the most important factor in the model, explaining more than $1 / 6$ of the variance. The most salient positive and negative loadings are reported in Table 1.

Table 1: The factor loadings

\begin{tabular}{|l|r|}
\hline Rejecting Islamism and the veil: & \\
\hline Not important: Woman wearing veil & 0.765 \\
\hline Important child qualities: religious faith & -0.703 \\
\hline Reject: politicians who don't believe in God are unfit for public office & 0.608 \\
\hline Feminism: & 0.778 \\
\hline Gender (female) & 0.684 \\
\hline Never attend religious services & 0.504 \\
\hline Reject: more than one wife & \\
\hline Upper strata distanced from the Army: & 0.733 \\
\hline Highest educational level attained & 0.728 \\
\hline No confidence: Armed Forces & \\
\hline Pro-democracy movement: & -0.641 \\
\hline Bad having a democratic political system & 0.558 \\
\hline Reject: more than one wife & \\
\hline Authoritarian personality: & -0.791 \\
\hline Important child qualities: tolerance and respect for other people & 0.553 \\
\hline Important child qualities: obedience & \\
\hline
\end{tabular}

Table 2 shows the correlations between the promax factors, and how closely rejecting Islamism and the veil; feminism; and the pro-democracy movement all interact in Muslim societies. It also should be noted with special emphasis that the pro-democracy movement is also closely linked to the rejection of polygamy, as the factor loadings above suggest.

Table 2: The factor correlations

\begin{tabular}{|l|c|c|l|l|}
\hline Component & $\begin{array}{l}\text { Rejecting } \\
\text { Islamism and } \\
\text { the veil }\end{array}$ & Feminism & $\begin{array}{l}\text { Upper strata } \\
\text { distanced from } \\
\text { the Army }\end{array}$ & $\begin{array}{l}\text { Pro-democracy } \\
\text { movement }\end{array}$ \\
\hline Feminism & $\mathbf{0 . 2 1 3}$ & & & \\
\hline $\begin{array}{l}\text { Upper strata distanced } \\
\text { from the Army }\end{array}$ & 0.034 & 0.015 & & \\
\hline $\begin{array}{l}\text { Pro-democracy } \\
\text { movement }\end{array}$ & $\mathbf{0 . 3 1 0}$ & $\mathbf{0 . 2 4 7}$ & 0.114 & 0.062 \\
\hline $\begin{array}{l}\text { Authoritarian } \\
\text { personality }\end{array}$ & 0.044 & 0.066 & 0.061 & \\
\hline
\end{tabular}


Table 3 and Graph 1 show the country values for the Muslim communities with complete data - Algeria, Bangladesh, Egypt, Indonesia, Iraq, Jordan, Nigeria, Turkey. Turkey and Bangladesh have a positive factor loading on the factor "rejecting Islamism and the veil", while Iraq and Egypt are the two strongest bastions of Islamist thinking. In Jordan and Turkey, feminist currents are strongest, while in Nigeria and Bangladesh, Muslim feminism receives the weakest support. Our data analysis also suggests that the upper strata distance from the Army is strongest in two countries which experienced military rule, Algeria and Indonesia, while in Turkey and Jordan, where the Army enjoys great popularity, this phenomenon is weakest. The pro-democracy currents are strongest in Bangladesh and Jordan and weakest in Iraq and Nigeria. The syndrome of the authoritarian personality is strongest in Algeria and Nigeria and weakest in Bangladesh and Iraq.

Table 3: The country values

\begin{tabular}{|l|c|r|r|r|r|}
\hline $\begin{array}{l}\text { Country/ } \\
\text { region }\end{array}$ & $\begin{array}{l}\text { Rejecting } \\
\text { Islamism and } \\
\text { the veil }\end{array}$ & Feminism & $\begin{array}{l}\text { Upper strata } \\
\text { distanced from } \\
\text { the Army }\end{array}$ & $\begin{array}{l}\text { Pro- } \\
\text { democracy } \\
\text { movement }\end{array}$ & $\begin{array}{l}\text { Authoritaria } \\
\text { n personality }\end{array}$ \\
\hline Algeria & -0.098 & -0.042 & 0.513 & -0.083 & 0.363 \\
\hline Bangladesh & 0.080 & -0.258 & -0.034 & 0.329 & -0.624 \\
\hline Egypt & -0.460 & 0.091 & 0.149 & 0.237 & -0.002 \\
\hline Indonesia & -0.234 & 0.007 & 0.358 & 0.288 & 0.204 \\
\hline Iraq & -0.741 & -0.109 & 0.217 & -0.647 & -0.053 \\
\hline Jordan & -0.200 & 0.271 & -0.277 & 0.301 & -0.039 \\
\hline Nigeria & -0.442 & -0.948 & 0.110 & -0.647 & 0.233 \\
\hline Turkey & 1.079 & 0.182 & -0.467 & -0.030 & 0.088 \\
\hline
\end{tabular}

Graph 1: The country values for rejecting Islamism and the veil, feminism and the prodemocracy movement

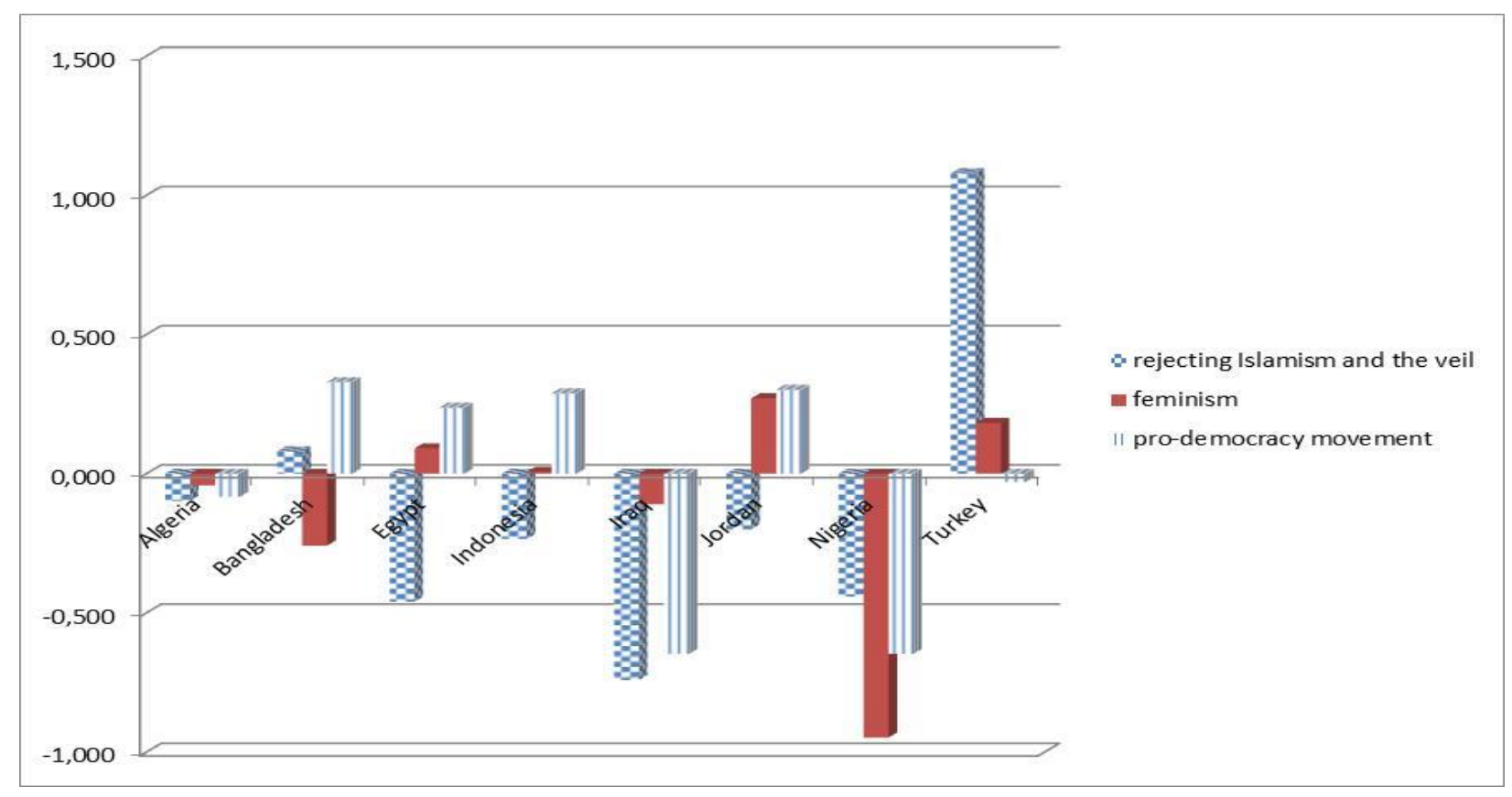




\section{Conclusions and prospects}

By focusing on an empirical analysis of the effects of gender ideology (Besamusca, Tijdens, Keune and Steinmetz, 2015) of Islamism we could highlight some of the factors which possibly explain the low labor force participation rates of women in the MENA region and which should be taken into consideration in future cross-national labor economic research. In recent economic theory, Carvalho (2013) maintained that Muslim veiling is a strategy for integration, enabling women to take up outside economic opportunities while preserving their reputation within the community. Our empirical data analysis on the basis of the "World Values Survey" clearly support a pessimistic view of the gender ideology of Islamism, so prevailing nowadays in large sections of the MENA region and many countries of the Muslim world in general.

The empirical results show that more than $70 \%$ of surveyed Muslim publics in our surveyed countries think that the veil is important or very important. Sizeable proportions not only support the veil, but also polygamy. Our evaluation also shows that more than a third and, in some countries even more than half of the entire Muslim population accepts male domestic violence against women. We show that Muslim Feminism, which implies according to our data analysis the rejection of the twin brothers - Islamism and the veil - and the democracy movement in the Muslim world are closely interrelated and could become the multiple basis for a real democratization of the region. Thus, it is imperative that the Western Feminism develops solidarity with Muslim Feminism, and that labor economics does not exclude anymore "the religious factor" from the analytical frameworks explaining low female labor force participation rates.

A host of indicators of an "Open Society orientation" significantly and negatively correlate with the acceptance of the veil and polygamy. After analyzing their correlation matrix, the SPSS XXII program extracted five factors, whose Eigenvalues corresponded to the standard criterion of being greater than 1.0. The factor "rejecting Islamism and the veil" is the most important factor in the model, explaining more than $1 / 6$ of the variance. We show the correlations between the promax factors, and how closely rejecting Islamism and the veil, feminism, and the pro-democracy movement all interact in Muslim societies. It also should be noted with special emphasis that the pro-democracy movement is also closely linked to the rejection of polygamy. For the West, it is time to take sides and to act in solidarity with the secular, feminist and pro-democracy movements in the region. To this day, Muslim majority countries, especially those which never experienced Communist or Kemalist rule, are the countries with the worst ranks on the World Economic Forum's "Closing the Global Gender Gap Index". ${ }^{24}$

And concerning the veil and Muslim mass migration to the developed countries in the zones of higher geographical latitude, there is a conspicuous silence in Western feminist literature on the path-breaking medical research on osteoporosis and vitamin D deficiency as a consequence for women of wearing the veil in adult life (Lips, 2007; El-Sonbaty, Riad, and Abdul-Ghaffar; 1996; Meddeb et al., 2005).

As even only a quick glance at the basic information about osteoporosis, available from the United States National Osteoporosis Foundation, ${ }^{25}$ spells out the consequences in old age: bones become weak and may break from a minor fall; bones have lost density or mass and the structure of the bone tissue has become abnormal, bones become weaker and are more likely to break. Far from being a "protective shield", Islamism is a prison for the women concerned, and the veil is an integral part of it.

\footnotetext{
${ }^{24} \mathrm{http} / / /$ reports.weforum.org/global-gender-gap-report-2015/

${ }^{25} \mathrm{http} / / /$ nof.org/
} 


\section{References}

Adamczyk, A. (2013). The effect of personal religiosity on attitudes toward abortion, divorce, and gender equality--does cultural context make a difference?. EurAmerica, 43(1), pp.213254.

Ahmed, L. (1992). Women and gender in Islam: historical roots of a modern debate. Yale University Press.

Alemán, J. and Woods, D. (2015). Value Orientations From the World Values Survey How Comparable Are They Cross-Nationally?. Comparative Political Studies, p.0010414015600458.

Alexander, A.C. and Welzel, C. (2011). Islam and patriarchy: how robust is Muslim support for patriarchal values?. International Review of Sociology, 21(2), pp.249-276.

Arik, H. (2015): Security, secularism and gender: the Turkish military's security discourse in relation to political Islam. Gender, Place \& Culture, pp.1-18.

Baldacchino, G. and Sammut, C. (2015). The Migration Crisis: No Human is Illegal. The Round Table, pp.1-3.

Besamusca, J., Tijdens, K., Keune, M. and Steinmetz, S. (2015). Working Women Worldwide. Age Effects in Female Labor Force Participation in 117 Countries. World Development, 74, 123-141.

Blaydes, L. and Linzer, D.A. (2012). Elite competition, religiosity, and anti-Americanism in the Islamic world. American Political Science Review, 106(02), pp.225-243.

Bouachrine, I. (2014). Women and Islam: myths, apologies, and the limits of feminist critique. Lexinton Books.

Carol, S. and Koopmans, R. (2013). Dynamics of contestation over Islamic religious rights in Western Europe. Ethnicities, 13(2), pp.165-190.

Carpenter, T.G. (2015). NATO's Worrisome Authoritarian Storm Clouds. Mediterranean Quarterly, 26(4), pp.37-48.

Carrera, S. and Lannoo, K. (2015). Treat the root causes of the asylum crisis, not the symptoms. CEPS Commentary, CEPS, Brussels.

Carvalho, J.P. (2013). Veiling. The Quarterly Journal of Economics, 128(1), 337-370.

Clauß, G. and Ebner, H. (1970). Grundlagen der Statistik für Psychologen, Pädagogen und Soziologen. Volk und Wissen Volkseigener Verlag.

Cooper, S. (2015). Generosity and barbarism: Within the empire of affect. Arena Magazine (Fitzroy, Vic), (138), p.2.

Coşar, S. and Yeğenoğlu, M. (2011). New grounds for patriarchy in Turkey? Gender policy in the age of AKP. South European Society and Politics, 16(4), pp.555-573.

Cronin, S. (2014). Anti-veiling Campaigns in the Muslim World: Gender, Modernism and the Politics of Dress. Routledge.

De Haan, A. (2015). Inclusive Growth: Beyond Safety Nets \& quest. European Journal of Development Research, 27(4), 606-622.

Dedeoglu, S. (2013). Veiled Europeanisation of welfare state in Turkey: Gender and social policy in the 2000s. Women's Studies International Forum, 41, pp. 7-13).

Donato, K. M., Piya, B. and Jacobs, A. (2014). The Double Disadvantage Reconsidered: Gender, Immigration, Marital Status, and Global Labor Force Participation in the 21st Century. International Migration Review, 48(s1), S335-S376.

El-Sonbaty, M.R. and Abdul-Ghaffar, N.U. (1996). Vitamin D deficiency in veiled Kuwaiti women. European Journal of Clinical Nutrition, 50(5), pp.315-318.

Gaddis, I. and Klasen, S. (2014). Economic development, structural change, and women's labor force participation. Journal of Population Economics, 27(3), 639-681. 
Ganguli, I., Hausmann, R. and Viarengo, M. (2014). Closing the gender gap in education: what is the state of gaps in labor force participation for women, wives and mothers. International Labour Review, 153(2), 173-207.

Ghumman, S. and Ryan, A.M. (2013). Not welcome here: Discrimination towards women who wear the Muslim headscarf. Human Relations, 66(5), pp.671-698.

Goldin, C. (1995). The U-Shaped Female Labor Force Function in Economic Development and Economic History, in T.P. Schultz (ed.). Investment in Women's Human Capital, Chicago: The University of Chicago Press.

Göle, N. ed. (2014). Islam and Public Controversy in Europe. Ashgate Publishing, Ltd.

Hann, C. (2015). The fragility of Europe's Willkommenskultur. Anthropology Today, 31(6), pp.1-2.

Helbling, M. (2014). Opposing Muslims and the Muslim Headscarf in Western Europe. European Sociological Review, 30(2), 242-257.

Hildebrandt, C. (2015). The Left Party in Germany. New Politics, 15(2), p.31.

Kabeer, N. (2012). Women's economic empowerment and inclusive growth: labour markets and enterprise development. International Development Research Centre.

Kabeer, N. and Natali, L. (2013). Gender Equality and Economic Growth: Is there a Win-Win?. IDS Working Papers, 2013(417), 1-58.

Kandiyoti, D. (2012). The travails of the secular: puzzle and paradox in Turkey. Economy and Society, 41(4), pp.513-531.

Lechman, E. and Kaur, H. 2015). Economic Growth and Female Labor Force ParticipationVerifying the U-Feminization Hypothesis. New Evidence for 162 Countries Over the Period 1990-2012 (January 18, 2015). Available at SSRN: http://ssrn.com/abstract=2551476 or http://dx.doi.org/10.2139/ssrn. 2551476

Lips, P. (2007). Vitamin D status and nutrition in Europe and Asia. The Journal of Steroid Biochemistry and Molecular Biology, 103(3), pp.620-625.

Lussier, D.N. and Fish, M.S. (2012). Muslims and Sex-Based Inequality: Evidence from CrossNational Surveys. In APSA 2012 Annual Meeting Paper, Available at SSRN: http://ssrn.com/abstract=2104631

Mahmood, S. (2011). Politics of piety: The Islamic revival and the feminist subject. Princeton University Press.

Martin, S.F. (2016). International Migration: Unilateral Policies Are Bound to Fail. Governance, 29(1), pp.5-7.

Meddeb, N., Sahli, H., Chahed, M., Abdelmoula, J., Feki, M., Salah, H., Frini, S., Kaabachi, N., Belkahia, C., Mbazaa, R. and Zouari, B. (2005). Vitamin D deficiency in Tunisia. Osteoporosis International, 16(2), pp.180-183.

Mertes, M. (2015). Too Big for Europe, Too Small for the World? The German Question Reconsidered. Israel Journal of Foreign Affairs, pp.11-13.

Mir-Hosseini, Z. (2011). Beyond 'Islam’vs 'feminism'. IDS Bulletin, 42(1), pp.67-77.

Moghadam, V.M. (1994). Gender and national identity: women and politics in Muslim societies. Palgrave Macmillan.

Moghadam, V.M. (2002). Islamic feminism and its discontents: Toward a resolution of the debate. Signs: Journal of Women in Culture and Society, 27(4), 1135-1171. 40(1).

Moghissi, H. ed. (2005). Women and Islam: critical concepts in sociology. New York: Routledge.

Mojab, S. (2001). Theorizing the politics of' Islamic Feminism'. Feminist Review, 69(1), pp.124-146.

Norris, P. and Inglehart, R.F. (2012). Muslim integration into Western cultures: Between origins and destinations. Political Studies, 60(2), pp.228-251. 
Ozcetin, H. (2013). 'Breaking the Silence': The Religious Muslim Women's Movement in Turkey. Journal of International Women's Studies, 11(1), pp.106-119.

Peters, M.A. and Besley, T. (2015). The Refugee Crisis and the Right to Political Asylum. Educational Philosophy and Theory, 47(13-14), pp.1367-1374.

Popper, K.S. (2012). The open society and its enemies. Routledge.

Steer, L., Ghanem, H., and Jalbout, M. (2014). Arab Youth: Missing Educational Foundations for a Productive Life? Brookings Institute, Center for Universal Education.

Stewart, J. (2015). The politics of European immigration. Quadrant, 59(11), p.39.

Tausch, A., Heshmati, A. and Karoui, H. (2014). The political algebra of global value change. General models and implications for the Muslim world. Hauppauge, NY: Nova Science Publishers.

Tsani, S., Paroussos, L., Fragiadakis, C., Charalambidis, I. and Capros, P. (2015). Female Labor Force Participation and Economic Development. In Economic and Social Development of the Southern and Eastern Mediterranean Countries (pp. 303-318). Springer International Publishing.

Verme P. (2015). Economic development and female labor participation in the Middle East and North Africa: a test of the U-shape hypothesis. IZA Journal of Labor \& Development, December 2015, 4:3.

Verme, P., Barry, A. G. and Guennouni, J. (2014). Female Labor Participation in the Arab World: Some Evidence from Panel Data in Morocco (September 1, 2014). World Bank Policy Research Working Paper No. 7031. Available at SSRN: http://ssrn.com/abstract=2496697 


\section{Data Appendix}

World Values Survey data file WVS_Longitudinal_1981_2014; Muslim respondents only

Appendix Table 1: PEW data on Muslim acceptancy of a Western dress style

\begin{tabular}{|l|c|}
\hline & $\begin{array}{c}\text { \% saying that the Western style of dress (without a } \\
\text { headscarf) is appropriate for women }\end{array}$ \\
\hline Lebanon & 49.0 \\
\hline Turkey & 32.0 \\
\hline Tunisia & 15.0 \\
\hline Egypt & 4.0 \\
\hline Iraq & 3.0 \\
\hline Saudi Arabia & 3.0 \\
\hline Pakistan & 2.0 \\
\hline
\end{tabular}

Appendix Table 2: PEW data on the insistence of Muslim society on female obedience in marriage

\begin{tabular}{|l|c|}
\hline & $\begin{array}{c}\text { \% of Muslims who completely or mostly agree that a } \\
\text { wife must obey her husband }\end{array}$ \\
\hline Malaysia & 96.0 \\
\hline Afghanistan & 94.0 \\
\hline Indonesia & 93.0 \\
\hline Tunisia & 93.0 \\
\hline Morocco & 92.0 \\
\hline Tajikistan & 89.0 \\
\hline Thailand & 89.0 \\
\hline Pakistan & 88.0 \\
\hline Bangladesh & 88.0 \\
\hline Palestinian Territories & 87.0 \\
\hline Egypt & 85.0 \\
\hline Uzbekistan & 84.0 \\
\hline Jordan & 80.0 \\
\hline Kyrgyzstan & 75.0 \\
\hline Lebanon & 74.0 \\
\hline Russia & 69.0 \\
\hline Turkey & 65.0 \\
\hline Azerbaijan & 58.0 \\
\hline Kazakhstan & 51.0 \\
\hline Bosnia Herzegovina & 45.0 \\
\hline Albania & 40.0 \\
\hline Kosovo & 34.0 \\
\hline & \\
\hline & \\
\hline
\end{tabular}


Appendix Table 3: World Values Survey data on global Muslim support for the veil and for polygamy

\begin{tabular}{|l|c|c|}
\hline & $\begin{array}{c}\text { \% Muslims saying woman } \\
\text { wearing the veil is very } \\
\text { important or important }\end{array}$ & $\begin{array}{c}\text { \% Muslims agreeing strongly } \\
\text { or agreeing: more than one } \\
\text { wife }\end{array}$ \\
\hline Algeria & 74.7 & 43.0 \\
\hline Bangladesh & 74.9 & 5.4 \\
\hline Egypt & 94.9 & 10.6 \\
\hline Indonesia & 73.8 & 19.8 \\
\hline Iran & 87.0 & 11.6 \\
\hline Iraq & 91.0 & 47.5 \\
\hline Jordan & 85.3 & 19.5 \\
\hline Nigeria & 77.1 & 74.0 \\
\hline Pakistan & & 1.1 \\
\hline Saudi Arabia & 91.9 & 42.7 \\
\hline Turkey & 14.9 & 15.9 \\
\hline
\end{tabular}

Appendix Table 4: the acceptancy of domestic violence among global publics and among global Muslim publics according to the World Values Survey

\begin{tabular}{|l|r|r|r|r|r|}
\hline & $\begin{array}{c}\text { \% of the } \\
\text { population } \\
\text { saying it is } \\
\text { justifiable } \\
\text { for a man to } \\
\text { beat his wife }\end{array}$ & $\begin{array}{c}\text { observ } \\
\text { ations }\end{array}$ & $\begin{array}{c}\text { \% of the Muslim } \\
\text { population } \\
\text { saying it is } \\
\text { justifiable for a } \\
\text { man to beat his } \\
\text { wife }\end{array}$ & $\begin{array}{c}\text { observ } \\
\text { ations }\end{array}$ & $\begin{array}{c}\text { Muslim } \\
\text { domestic } \\
\text { violence } \\
\text { above/belo } \\
\text { w overall } \\
\text { society }\end{array}$ \\
\hline Georgia & 9.3 & 2675 & 4.8 & 83 & -4.5 \\
\hline Canada & 6.4 & 2141 & 5.6 & 36 & -0.8 \\
\hline Indonesia & 11.5 & 1996 & 11.2 & 1840 & -0.3 \\
\hline France & 9.2 & 1001 & 12.8 & 47 & 3.6 \\
\hline Ethiopia & 22.4 & 1490 & 17.8 & 157 & -4.6 \\
\hline Trinidad and Tobago & 16.5 & 1995 & 17.9 & 123 & 1.4 \\
\hline Bulgaria & 26.3 & 967 & 19.1 & 110 & -7.2 \\
\hline Great Britain & 12.4 & 1019 & 19.5 & 41 & 7.1 \\
\hline Jordan & 19.5 & 2399 & 19.8 & 2333 & 0.3 \\
\hline Turkey & 20.0 & 2936 & 19.9 & 2903 & -0.1 \\
\hline Cyprus & 17.8 & 2044 & 20.9 & 497 & 3.1 \\
\hline Netherlands & 11.3 & 2888 & 20.9 & 43 & 9.6 \\
\hline Qatar & 23.4 & 1057 & 23.4 & 1057 & xx \\
\hline Slovenia & 19.1 & 2051 & 25.8 & 31 & 6.7 \\
\hline Iran & 26.0 & 2660 & 25.9 & 2617 & -0.1 \\
\hline
\end{tabular}




\begin{tabular}{|c|c|c|c|c|c|}
\hline Libya & 30.2 & 2068 & 29.8 & 2015 & -0.4 \\
\hline Pakistan & 30.3 & 1201 & 30.2 & 1196 & -0.1 \\
\hline Azerbaijan & 30.5 & 1002 & 30.4 & 974 & -0.1 \\
\hline South Africa & 50.6 & 6438 & 31.3 & 83 & -19.3 \\
\hline Tunisia & 31.3 & 1189 & 31.3 & 1189 & $\mathrm{xx}$ \\
\hline China & 34.8 & 3824 & 35.0 & 100 & 0.2 \\
\hline Morocco & 35.1 & 2317 & 35.1 & 2303 & 0.0 \\
\hline Kyrgyzstan & 37.2 & 1495 & 35.8 & 1331 & -1.4 \\
\hline Kazakhstan & 36.8 & 1502 & 37.1 & 757 & 0.3 \\
\hline Yemen & 38.0 & 985 & 38.0 & 985 & $\mathrm{XX}$ \\
\hline Germany & 27.3 & 4038 & 41.0 & 139 & 13.7 \\
\hline Palestinian Territories & 44.4 & 994 & 44.2 & 991 & -0.2 \\
\hline Kuwait & 44.6 & 1261 & 44.6 & 1261 & $\mathrm{XX}$ \\
\hline Uzbekistan & 44.7 & 1499 & 45.1 & 1425 & 0.4 \\
\hline Singapore & 44.1 & 1970 & 45.6 & 320 & 1.5 \\
\hline Russia & 25.1 & 4406 & 46.6 & 251 & 21.5 \\
\hline Nigeria & 53.2 & 1759 & 46.8 & 758 & -6.4 \\
\hline Malaysia & 48.8 & 2501 & 47.9 & 1509 & -0.9 \\
\hline Philippines & 48.2 & 1200 & 48.6 & 74 & 0.4 \\
\hline Burkina Faso & 51.5 & 1477 & 50.4 & 782 & -1.1 \\
\hline Ghana & 37.3 & 3060 & 51.7 & 393 & 14.4 \\
\hline Sweden & 9.3 & 2182 & 53.3 & 30 & 44.0 \\
\hline Lebanon & 46.4 & 1200 & 53.7 & 622 & 7.3 \\
\hline Algeria & 59.4 & 1139 & 59.2 & 1133 & -0.2 \\
\hline Bahrain & 59.3 & 1200 & 59.3 & 1200 & $\mathrm{XX}$ \\
\hline Egypt & 61.1 & 1523 & 61.1 & 1523 & $\mathrm{XX}$ \\
\hline Mali & 62.1 & 1352 & 62.4 & 1263 & 0.3 \\
\hline Rwanda & 73.1 & 3030 & 63.9 & 305 & -9.2 \\
\hline Iraq & 65.1 & 1197 & 65.1 & 1185 & 0.0 \\
\hline Thailand & 49.1 & 2727 & 69.2 & 65 & 20.1 \\
\hline India & 55.0 & 3293 & 70.1 & 355 & 15.1 \\
\hline
\end{tabular}


Appendix Table 5: The partial correlations of the accepting the veil (constant: gender) estimated from individual level World Values Survey data

\begin{tabular}{|l|c|c|c|}
\hline & \multicolumn{3}{|c|}{ Accepting the veil } \\
\hline & Correlation & $\begin{array}{c}\text { Error p } \\
\text { (two-tailed) }\end{array}$ & $\begin{array}{c}\text { Degrees of } \\
\text { freedom }\end{array}$ \\
\hline $\begin{array}{l}\text { Politicians who don't believe in God are unfit for } \\
\text { public office }\end{array}$ & 0.302 & 0.000 & 13160 \\
\hline $\begin{array}{l}\text { Violation of Islam for male and female } \\
\text { university students to attend classes together }\end{array}$ & 0.286 & 0.000 & 3314 \\
\hline Only laws of the Shari'a & 0.263 & 0.000 & 11073 \\
\hline Men make better political leaders than women do & 0.241 & 0.000 & 16889 \\
\hline $\begin{array}{l}\text { A truly Islamic country should not have a } \\
\text { parliament with the right to pass laws }\end{array}$ & 0.218 & 0.000 & 2743 \\
\hline $\begin{array}{l}\text { University is more important for a boy than for a } \\
\text { girl }\end{array}$ & 0.208 & 0.000 & 17196 \\
\hline Reject neighbours: Jews & 0.202 & 0.000 & 6452 \\
\hline $\begin{array}{l}\text { Religious leaders should influence how people } \\
\text { vote }\end{array}$ & 0.195 & 0.000 & 12777 \\
\hline $\begin{array}{l}\text { Exposure to the culture of the US and other } \\
\text { Western countries harmful effect on our country }\end{array}$ & 0.168 & 0.000 & 1091 \\
\hline $\begin{array}{l}\text { Islam requires country with majority of Muslims } \\
\text { be governed by men of Islamic learning }\end{array}$ & 0.161 & 0.000 & 1081 \\
\hline Wife must obey & 0.139 & 0.000 & 17434 \\
\hline Important child qualities: obedience & 0.134 & 0.000 & 17569 \\
\hline $\begin{array}{l}\text { Islam requires that political rights of non- } \\
\text { Muslims should be inferior to those of Muslims }\end{array}$ & 0.116 & 0.000 & 2957 \\
\hline No confidence: The European Union & 0.108 & 0.000 & 1041 \\
\hline No confidence: The United Nations & -0.144 & 0.000 & 15321 \\
\hline Important child qualities: hard work & & 0.000 & 14758 \\
\hline
\end{tabular}


Appendix Table 6: The partial correlations of accepting polygamy (constant: gender) estimated from individual level World Values Survey data

\begin{tabular}{|l|c|c|r|}
\hline & \multicolumn{3}{|c|}{ More than one wife } \\
\hline & Correlation & Error p & $\begin{array}{c}\text { Degrees of } \\
\text { freedom }\end{array}$ \\
\hline No confidence: NATO & 0.437 & 0.000 & 1963 \\
\hline Reject neighbours: Homosexuals & 0.257 & 0.000 & 15024 \\
\hline Reject neighbours: Jews & 0.221 & 0.000 & 6445 \\
\hline $\begin{array}{l}\text { University is more important for a boy than for a } \\
\text { girl }\end{array}$ & 0.188 & 0.000 & 18310 \\
\hline Men make better political leaders than women do & 0.170 & 0.000 & 18008 \\
\hline $\begin{array}{l}\text { Democracies are indecisive and have too much } \\
\text { squabbling }\end{array}$ & 0.168 & 0.000 & 15147 \\
\hline Justifiable: avoiding a fare on public transport & 0.150 & 0.000 & 12976 \\
\hline $\begin{array}{l}\text { Islam requires country with majority of Muslims } \\
\text { be governed by men of Islamic learning }\end{array}$ & 0.137 & 0.000 & 2247 \\
\hline No confidence: Parliament & 0.131 & 0.000 & 13948 \\
\hline Important child qualities: obedience & 0.124 & 0.000 & 18705 \\
\hline $\begin{array}{l}\text { A truly Islamic country should not have a } \\
\text { parliament with the right to pass laws }\end{array}$ & 0.123 & 0.000 & 3923 \\
\hline Competition harmful & 0.121 & 0.000 & 1274 \\
\hline Justifiable: cheating on taxes & 0.117 & 0.000 & 11561 \\
\hline
\end{tabular}




\section{A factor analytical model}

$\mathrm{N}=9995 ; 5$ factors with an Eigenvalue above or equal to 1.0 were interpreted; $53,965 \%$ of total variance is explained

Appendix Table 7: The variables of the model

\begin{tabular}{|l|l|l|l|l|}
\hline & Mean & Std. Dev. & N & $\begin{array}{l}\text { Highest numerical value } \\
\text { suggests interpreting the } \\
\text { variable as }\end{array}$ \\
\hline $\begin{array}{l}\text { Important child qualities: } \\
\text { tolerance and respect for } \\
\text { other people }\end{array}$ & 0.660 & 0.474 & 9995 & $\begin{array}{l}\text { Important child qualities: } \\
\text { tolerance and respect for other } \\
\text { people }\end{array}$ \\
\hline $\begin{array}{l}\text { Important child qualities: } \\
\text { religious faith }\end{array}$ & 0.740 & 0.437 & 9995 & $\begin{array}{l}\text { Important child qualities: } \\
\text { religious faith }\end{array}$ \\
\hline $\begin{array}{l}\text { Important child qualities: } \\
\text { obedience }\end{array}$ & 0.480 & 0.500 & 9995 & $\begin{array}{l}\text { Important child qualities: } \\
\text { obedience }\end{array}$ \\
\hline $\begin{array}{l}\text { University is more } \\
\text { important for a boy than for } \\
\text { a girl }\end{array}$ & 2.800 & 1.074 & 9995 & $\begin{array}{l}\text { University is equally important } \\
\text { for a boy and for a girl }\end{array}$ \\
\hline $\begin{array}{l}\text { Traits in a woman: Woman } \\
\text { wearing veil }\end{array}$ & 2.250 & 1.499 & 9995 & $\begin{array}{l}\text { not important: Woman wearing } \\
\text { veil }\end{array}$ \\
\hline More than one wife & 3.410 & 1.174 & 9995 & reject: more than one wife \\
\hline Wife must obey & 1.870 & 0.986 & 9995 & reject: wife must obey \\
\hline Confidence: Armed Forces & 1.970 & 0.936 & 9995 & no confidence: Armed Forces \\
\hline $\begin{array}{l}\text { Political system: Having a } \\
\text { democratic political system }\end{array}$ & 1.490 & 0.654 & 9995 & $\begin{array}{l}\text { bad having a democratic } \\
\text { political system }\end{array}$ \\
\hline $\begin{array}{l}\text { How often do you attend } \\
\text { religious services }\end{array}$ & 3.980 & 2.834 & 9995 & never attend religious services \\
\hline $\begin{array}{l}\text { Politicians who don't } \\
\text { believe in God are unfit for } \\
\text { public office }\end{array}$ & 1.910 & 1.246 & 9995 & $\begin{array}{l}\text { reject: politicians who don't } \\
\text { believe in God are unfit for } \\
\text { public office }\end{array}$ \\
\hline Sex & 1.440 & 0.497 & 9995 & Gender (female) \\
\hline $\begin{array}{l}\text { Highest educational level } \\
\text { attained }\end{array}$ & 4.370 & 2.343 & 9995 & $\begin{array}{l}\text { Highest educational level } \\
\text { attained }\end{array}$ \\
\hline
\end{tabular}


Appendix Table 8: estimates of factor analytical communalities

\begin{tabular}{|l|c|}
\hline Highest numerical value suggests interpreting the variable as & $\begin{array}{c}\text { Percentage of total } \\
\text { variance explained }\end{array}$ \\
\hline Important child qualities: tolerance and respect for other people & 0.647 \\
\hline Important child qualities: religious faith & 0.544 \\
\hline Important child qualities: obedience & 0.477 \\
\hline University is equally important for a boy and for a girl & 0.444 \\
\hline Not important: Woman wearing veil & 0.632 \\
\hline Reject: more than one wife & 0.508 \\
\hline Reject: wife must obey & 0.398 \\
\hline No confidence: Armed Forces & 0.662 \\
\hline Bad having a democratic political system & 0.547 \\
\hline Never attend religious services & 0.519 \\
\hline $\begin{array}{l}\text { Reject: politicians who don't believe in God are unfit for public } \\
\text { office }\end{array}$ & 0.375 \\
\hline Gender (female) & 0.650 \\
\hline Highest educational level attained & 0.611 \\
\hline
\end{tabular}

Appendix Table 9: how the five factors explain the variance of the variables

\begin{tabular}{|c|c|c|c|}
\hline & Eigenvalue & $\begin{array}{l}\% \text { of variance } \\
\text { explained }\end{array}$ & $\begin{array}{l}\text { Cumulated percentage } \\
\text { of variance explained }\end{array}$ \\
\hline $\begin{array}{l}\text { Rejecting Islamism and } \\
\text { the veil }\end{array}$ & 2.172 & 16.710 & 16.710 \\
\hline Feminism & 1.504 & 11.571 & 28.282 \\
\hline $\begin{array}{l}\text { Upper strata distanced } \\
\text { from the Army }\end{array}$ & 1.256 & 9.662 & 37.944 \\
\hline $\begin{array}{l}\text { Pro-democracy } \\
\text { movement }\end{array}$ & 1.080 & 8.310 & 46.254 \\
\hline $\begin{array}{l}\text { Authoritarian } \\
\text { personality }\end{array}$ & 1.002 & 7.711 & 53.965 \\
\hline
\end{tabular}


Appendix Table 10: Rejecting Islamism and the veil - the factor analytical model, based on promax rotation

\begin{tabular}{|l|c|c|c|c|c|}
\hline & $\begin{array}{c}\text { Rejecting } \\
\text { Islamism } \\
\text { and the } \\
\text { veil }\end{array}$ & Feminism & $\begin{array}{c}\text { Upper } \\
\text { strata } \\
\text { distanced } \\
\text { from the } \\
\text { Army }\end{array}$ & $\begin{array}{c}\text { Pro- } \\
\text { democracy } \\
\text { movement }\end{array}$ & $\begin{array}{c}\text { Authoritari } \\
\text { an } \\
\text { personality }\end{array}$ \\
\hline $\begin{array}{l}\text { Important child } \\
\text { qualities: tolerance and } \\
\text { respect for other people }\end{array}$ & -0.113 & 0.052 & -0.051 & -0.060 & $\mathbf{- 0 . 7 9 1}$ \\
\hline $\begin{array}{l}\text { Important child } \\
\text { qualities: religious faith }\end{array}$ & $\mathbf{- 0 . 7 0 3}$ & -0.033 & 0.035 & -0.060 & 0.096 \\
\hline $\begin{array}{l}\text { Important child } \\
\text { qualities: obedience }\end{array}$ & -0.341 & 0.032 & -0.056 & -0.221 & $\mathbf{0 . 5 5 3}$ \\
\hline $\begin{array}{l}\text { University is equally } \\
\text { important for a boy and } \\
\text { for a girl }\end{array}$ & 0.296 & 0.460 & 0.150 & 0.498 & 0.290 \\
\hline $\begin{array}{l}\text { Not important: Woman } \\
\text { wearing veil }\end{array}$ & $\mathbf{0 . 7 6 5}$ & 0.182 & -0.123 & 0.103 & 0.105 \\
\hline $\begin{array}{l}\text { Reject: more than one } \\
\text { wife }\end{array}$ & 0.165 & $\mathbf{0 . 5 0 4}$ & -0.101 & $\mathbf{0 . 5 5 8}$ & -0.108 \\
\hline Reject: wife must obey & 0.409 & 0.468 & 0.244 & 0.374 & 0.062 \\
\hline $\begin{array}{l}\text { No confidence: Armed } \\
\text { Forces }\end{array}$ & -0.218 & -0.009 & $\mathbf{0 . 7 2 8}$ & -0.220 & -0.063 \\
\hline $\begin{array}{l}\text { Bad having a } \\
\text { democratic political } \\
\text { system }\end{array}$ & 0.046 & 0.125 & -0.081 & $\mathbf{- 0 . 6 4 1}$ & 0.029 \\
\hline $\begin{array}{l}\text { Never attend religious } \\
\text { services }\end{array}$ & 0.138 & $\mathbf{0 . 6 8 4}$ & 0.050 & -0.033 & 0.016 \\
\hline $\begin{array}{l}\text { Reject: politicians who } \\
\text { don't believe in God are } \\
\text { unfit for public office }\end{array}$ & $\mathbf{0 . 6 0 8}$ & 0.091 & 0.061 & 0.137 & 0.011 \\
\hline Gender (female) & -0.001 & $\mathbf{0 . 7 7 8}$ & -0.097 & 0.092 & -0.009 \\
\hline $\begin{array}{l}\text { Highest educational } \\
\text { level attained }\end{array}$ & 0.143 & -0.015 & $\mathbf{0 . 7 3 3}$ & 0.327 & 0.108 \\
\hline
\end{tabular}


Appendix Table 11: Definition of the factors

\begin{tabular}{|l|r|}
\hline Rejecting Islamism and the veil: & \\
\hline Not important: Woman wearing veil & 0.765 \\
\hline Important child qualities: religious faith & -0.703 \\
\hline Reject: politicians who don't believe in God are unfit for public office & 0.608 \\
\hline Reject: wife must obey & 0.409 \\
\hline Important child qualities: obedience & -0.341 \\
\hline University is equally important for a boy and for a girl & 0.296 \\
\hline No confidence: Armed Forces & -0.218 \\
\hline Reject: more than one wife & 0.165 \\
\hline Highest educational level attained & 0.143 \\
\hline Never attend religious services & 0.138 \\
\hline Important child qualities: tolerance and respect for other people & -0.113 \\
\hline Bad having a democratic political system & 0.046 \\
\hline Gender (female) & -0.001 \\
\hline
\end{tabular}

\begin{tabular}{|l|r|}
\hline Feminism: & \\
\hline Gender (female) & 0.778 \\
\hline Never attend religious services & 0.684 \\
\hline Reject: more than one wife & 0.504 \\
\hline Reject: wife must obey & 0.468 \\
\hline University is equally important for a boy and for a girl & 0.460 \\
\hline Not important: Woman wearing veil & 0.182 \\
\hline Bad having a democratic political system & 0.125 \\
\hline Reject: politicians who don't believe in God are unfit for public office & 0.091 \\
\hline Important child qualities: tolerance and respect for other people & 0.052 \\
\hline Important child qualities: religious faith & -0.033 \\
\hline Important child qualities: obedience & 0.032 \\
\hline Highest educational level attained & -0.015 \\
\hline No confidence: Armed Forces & -0.009 \\
\hline
\end{tabular}

\begin{tabular}{|l|r|}
\hline Upper strata distanced from the Army: & \\
\hline Highest educational level attained & 0.733 \\
\hline No confidence: Armed Forces & 0.728 \\
\hline Reject: wife must obey & 0.244 \\
\hline University is equally important for a boy and for a girl & 0.150 \\
\hline Not important: Woman wearing veil & -0.123 \\
\hline Reject: more than one wife & -0.101 \\
\hline Gender (female) & -0.097 \\
\hline Bad having a democratic political system & -0.081 \\
\hline Reject: politicians who don't believe in God are unfit for public office & 0.061 \\
\hline Important child qualities: obedience & -0.056 \\
\hline Important child qualities: tolerance and respect for other people & -0.051 \\
\hline Never attend religious services & 0.050 \\
\hline Important child qualities: religious faith & 0.035 \\
\hline
\end{tabular}




\begin{tabular}{|l|c|}
\hline Pro-democracy movement: & \\
\hline Bad having a democratic political system & -0.641 \\
\hline Reject: more than one wife & 0.558 \\
\hline University is equally important for a boy and for a girl & 0.498 \\
\hline Reject: wife must obey & 0.374 \\
\hline Highest educational level attained & 0.327 \\
\hline Important child qualities: obedience & -0.221 \\
\hline No confidence: Armed Forces & -0.220 \\
\hline Reject: politicians who don't believe in God are unfit for public office & 0.137 \\
\hline Not important: Woman wearing veil & 0.103 \\
\hline Gender (female) & 0.092 \\
\hline Important child qualities: tolerance and respect for other people & -0.060 \\
\hline Important child qualities: religious faith & -0.060 \\
\hline Never attend religious services & -0.033 \\
\hline
\end{tabular}

\begin{tabular}{|l|r|}
\hline Authoritarian personality: & \\
\hline Important child qualities: tolerance and respect for other people & -0.791 \\
\hline Important child qualities: obedience & 0.553 \\
\hline University is equally important for a boy and for a girl & 0.290 \\
\hline Reject: more than one wife & -0.108 \\
\hline Highest educational level attained & 0.108 \\
\hline Not important: Woman wearing veil & 0.105 \\
\hline Important child qualities: religious faith & 0.096 \\
\hline No confidence: Armed Forces & -0.063 \\
\hline Reject: wife must obey & 0.062 \\
\hline Bad having a democratic political system & 0.029 \\
\hline Never attend religious services & 0.016 \\
\hline Reject: politicians who don't believe in God are unfit for public office & 0.011 \\
\hline Gender (female) & -0.009 \\
\hline
\end{tabular}

